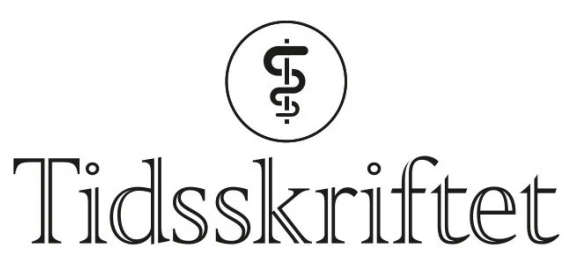

DEN NORSKE LEGEFORENING

\title{
Imponerende om røykeavvenning
}

ANMELDELSER

FRODE GALLEFOSS

Seksjon for lungesykdommer

Sørlandet sykehus

Kristiansand

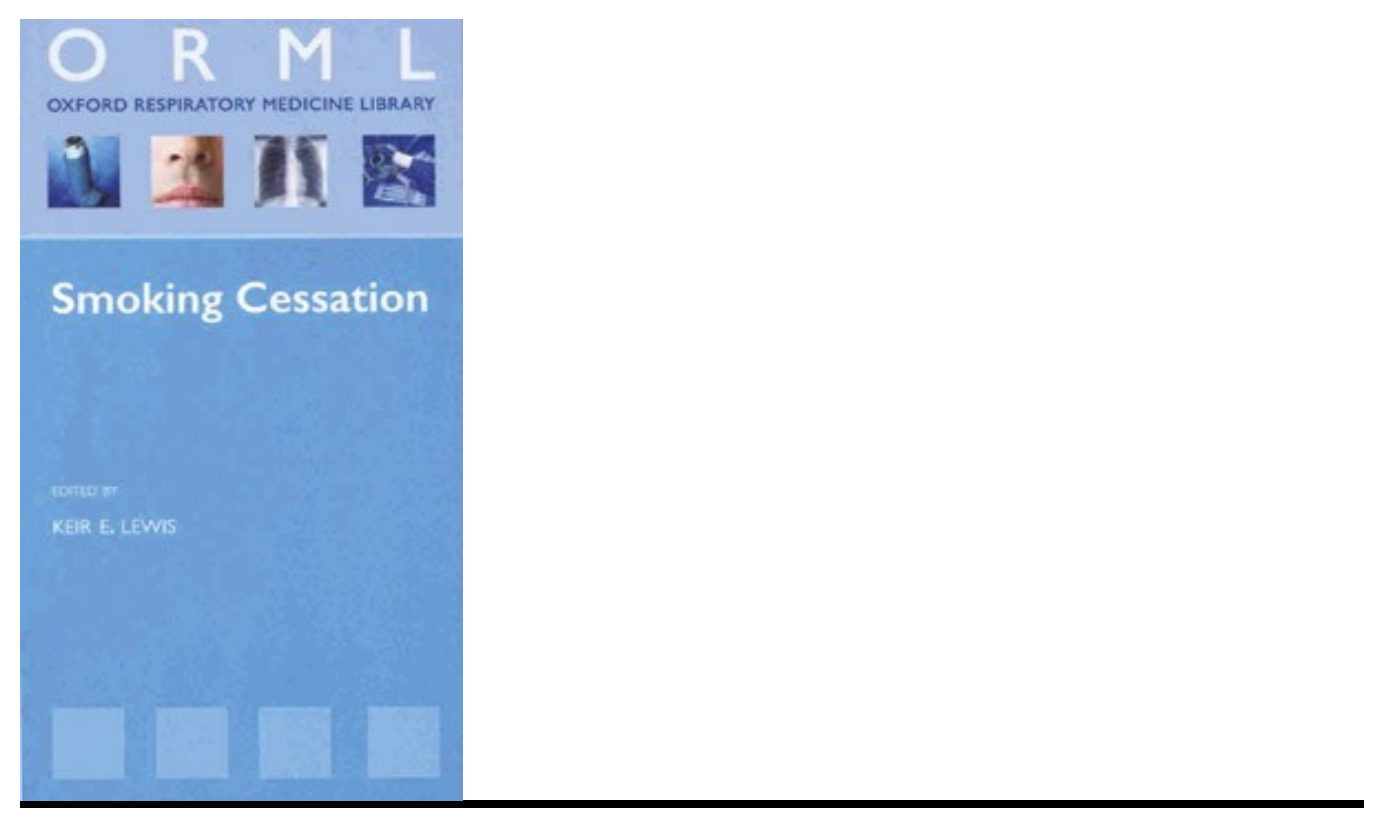

Lewis, Keir E

Smoking cessation

164 s, tab, ill. Oxford: Oxford University Press, 2010. Pris GBP 6

ISBN 978-0-19-955625-0

Dette er en kortfattet bok om røykeavvenning hvor bidragsyterne har som mål å levere en kompakt, praktisk og kunnskapsbasert veiledning og gi gode råd i dagligdagse, kliniske situasjoner. Målgruppen er leger og sykepleiere som behandler røykere, samt personer med ansvar for medisinsk og annen helsefaglig utdanning. 
Boken består av 15 kapitler med følgende temaer: røykingens epidemiologi/historie i et verdensperspektiv, fysiologiske og psykiske effekter av røyking, metoder for

røykeavvenning og farmakologiske og ikke-farmakologiske hjelpemidler. Så følger åtte kapitler om hvilke motivasjonsfaktorer som er særlig viktige, og hvilke medikamenter som, ifølge litteraturen, er effektive ved kols (kronisk obstruktiv lungesykdom),

koronarsykdom, planlagt kirurgi, graviditet, kreft, psykisk sykdom samt for unge røykere og jenter/kvinner. I tillegg omtaler forfatterne i egne kapitler diverse andre medisinske tilstander og fremtidens farmakologi. Her diskuterer de også forhold som kols og depresjon, røyking og sårtilheling, viktigheten av røykestopp minst åtte uker før planlagt kirurgi og røyking og osteoporose.

Kapitlene begynner med oppsummerte hovedpunkter og har boksdiagrammer med punktvise oppsummeringer som bidrar til god oversikt over temaene. Avslutningsvis diskuterer forfatterne kasuistikker, viser praktiske konsultasjonsark og flytdiagrammer til bruk i røykeavvenning, kommer med forslag til tilnærming overfor høyrisikogrupper og henviser til aktuelle nettsider. De viser også flere praktiske eksempler på hvordan man skal henvende seg til politikere og helsemyndigheter for å foreslå røykeforebyggende tiltak. Boken er redigert av lungelege og indremedisiner Keir Lewis og skrevet av til sammen 12 forfattere, de fleste av dem unge og engelske, med åpenbar klinisk erfaring.

Dette er en imponerende kraftpakke om røykeavvenning; lettlest, komprimert, oversiktlig, praktisk og på alle måter klinisk. Det er flere viktige kliniske presiseringer av ren praktisk karakter, som det rett og slett er flott å se på trykk, f.eks. at en lege som vil henvise en pasient til en spesialist i røykeavvenning, ikke bare skal anmode pasienten om å gjøre det selv, men faktisk bør gjøre det for pasienten. Videre er det et klart søkelys på hvor viktig det er med oppfølgingssamtaler etter røykestopp.

Forfatterne fremhever ofte de gylne øyeblikkene som kan øke motivasjonen og mestringen, og som mange helsearbeidere bør være oppmerksomme på i sitt kliniske arbeid. Disse poengteringene er nyttig informasjon for de fleste og bør bidra til å øke årvåkenheten hos helsearbeidere som snakker med røykere. Især gir de i kapitlet om røyking og kreft flere overbevisende grunner til økt røykeavvenningsinnsats i denne gruppen.

En rett og slett imponerende liten bok om et svært viktig tema - som jeg er glad for å ha lest.

Publisert: 4. mars 2011. Tidsskr Nor Legeforen. DOI: 10.4045/tidsskr.10.1372

(C) Tidsskrift for Den norske legeforening 2023. Lastet ned fra tidsskriftet.no 26. april 2023. 